\title{
We Need Resilient School Leaders in the face of Chaos and Complexity ${ }^{1}$
}

\author{
Mustafa Ozmusul $^{2}$
}

\begin{abstract}
We experience some rapid and unexpected changes especially within the incoherent and asunder school policies and implementations that are unsuitable for the demands and expectations of school stakeholders. Furthermore, the internal and other external obstacles and non-ideal situations such as lack of resources, negative school climate, less motivation, organizational conflicts, cultural matters, depersonalization, or resist to change surround the schools today. All these tend to produce serious organizational stress and turn into organizational viruses at the school level. Exploring the non-ideal situations affecting today schools, the present study conceptualizes a resilient leadership model with reference to the school system in the face of chaos and complexity. Although describing the resilient leaders seems difficult we can say that resilient leaders do not seek pretext for struggling against difficulties, and when non-ideal situations occur they can shake but stand up. Such leaders that we expect like a tree which can withstand a storm run in downpour, like a dam which can hinder strong waves, or like a flower which can blossom in the snow. They may not be superman or supergirl but at least they are mentally, emotionally, socially, ethically, and physically strong humans who beat the odds. In turn, resilient leadership can be defined as displaying high level of endeavor to overcome the both internal and external obstacles that the organization faces, and generating different solutions despite the fact that many non-ideal situations affect the organization. At the end of the study, in the face of such situations, some potential characteristics of the resilient school leaders are suggested.
\end{abstract}

Keywords: resilient leadership, school leadership, leadership development, chaos and leadership

\section{Introduction}

We experience some rapid and unexpected changes especially within the incoherent and asunder school policies and implementations that are unsuitable for the demands and expectations of school stakeholders. Furthermore, the internal and other external obstacles and non-ideal situations such as lack of resources, negative school climate, less motivation, organizational conflicts, cultural

\footnotetext{
${ }^{1}$ This study is a extended version of the paper presented at the $5^{\text {th }}$ International Symposium on Chaos, Complexity and Leadership (ICCLS) between 11-12 December 2017 in Ankara,Turkey.

${ }^{2}$ Harran University, Turkey, mustafaozmusul [at] harran.edu.tr
} 
matters, depersonalization, or resist to change surround the schools today. All these obstacles tend to produce serious organizational stress and turn into organizational viruses at the school level.

One of the prior issues in education policy has been school leadership in the world. In particular, paying attention to school autonomy and international learning outputs brings up school leadership to the agenda of school improvement. School leadership also has a key role in improving the efficiency and equity of schooling. But, many principals consider that they face heavy workloads in the OECD countries (OECD, 2008).

School leadership today does not entail only work in the school but work in the environment beyond their school. For the principals, this has been twice challenging that extends their role from fulfilling policy to practicing leadership in the school and out of school (Hargreaves, Halász, \& Pont, 2008). Moreover, local site management, increased accountability, the tension between management and leadership, altered relationships with community, and dilemmas related to school choice have changed considerably the role of principal, from international context (Whitaker, 2003). Also, during in the process of education reform, school principals seem to be mediating agents standing at the school doorstep, from extra-school to intra-school environments. This mediating role is another challenge for them and needs to behave in a position between the demands of a national reform policy and teacher's perceptions and expectations (Shaked \& Schechter, 2017).

Numerous studies have shown various challenges that principals face in the school: Bayar (2016) found that some principals in Amasya/Turkey did not satisfy their job because of the difficulties they face in their schools such as violence, families' negative attitudes towards school, immigrant students/families from abroad, syndicalism, teachers' attitudes and behaviors to principals, and increasing of undesired behaviors in classroom/school. $\mathrm{Ng}$ (2015) indicated that aspiring principals from the Leaders in Education Programme (LEP) in Singapore reported main challenges as adapting to a new organizational environment and role, working with staff and other stakeholders, and meeting the expectations of others while trying to live true to one's values. According to the study by Preston, Jakubiec, \& Kooymans (2013) the rural principals candidates mostly from American, Canadian, and Australian context stated following challenges: Hiring disadvantage, juggling diverse responsibilities, lack of professional development and resources, gender discrimination, and issues surrounding school accountability and change.

A highly representative study by Wise (2015) indicated that many public school principals in the US, faced serious obstacles never before seen in education such as overwhelming effects of poverty, increasing pressures on student achievement, the breakdown of communities, lack of financial resources, and a host of other issues. De Jong, Grundmeyer, \& Yankey (2017) revealed four issues producing job dissatisfaction as follows: high job demands with unreasonable expectations, managing difficult stakeholders, problematic work/life balance, and lack of support. Obtaining the data after several years Shoho, \& Barnett (2010) shown the challenges that new principals face regarding instructional leadership, managerial issues (i.e.s budgeting and human resources), community issues involving climate, politics, and differing expectations from parents. 
As a result, all these challenges have shown that school leadership entails to work in a highly complex environment. And we can say that succeed school leaders in today and future are those who perceive the complex environment, and respond to the challenges in this environment wisely.

\section{Resilient School Leadership (RSL)}

The questions on the desk are as follows:

"In the face of many challenges what can the school leaders do?"

"What can the school leaders do?"

"How can they act?"

"Who should be school leader?"

After about ten years school teaching experience and five year faculty member at the university experience with head of the department, I can say that the school leaders should be resilient, especially in beating the odds.

Although describing the resilient leaders seems difficult we can say that resilient leaders do not seek pretext for struggling against difficulties, and when non-ideal situations occur they can shake but stand up. Such leaders that we expect like a tree which can withstand a storm run in downpour, like a dam which can hinder strong waves, or like a flower which can blossom in the snow. They may not be superman or supergirl but at least they are mentally, emotionally, socially, ethically, and physically strong humans who beat the odds.

In turn, resilient leadership can be defined as displaying high level of endeavor to overcome the both internal and external obstacles that the organization faces, and generating different solutions despite the fact that many non-ideal situations affect the organization.

Today's school leaders who beat the odds seem to be resilient mentally, emotionally, socially, ethically, and physically. Some explanations can be given in five dimensions as follows:

\section{Mentally Resilience}

Resilient School Leaders focus on a vision that means a common picture for all against the obstacles they face. Focusing the vision the leaders think big, pay attention to the common aims, and see the obstacles as the problems that can be solved. In the history many visionary examples were possible such as Ataturk, Mandela, Gandhi, Lincoln, Teresa, and so on. In the school context, for instance; to improve the school climate, a resilient principal can focus on "happy school" vision in and out school although he or she face the conflicts, negative climate, lack of motivation among the people and students. 
It is easy and simple way to seek pretext instead of coping with, when the challenges appear. Just as Sagan (1997) said "It is better to light a candle than to curse the darkness". From this aspect, the leader should find and light the needed candle against the darkness of the obstacles he or she faces. Resilient school leaders do not let their schools to be plunged into the darkness.

Such leaders also are open to new ideas. Otherwise, insisting only one way, making decision without searching more ideas, maintaining clichés, and also falling into "group think" trap can destroy organizational creativity. For that, coping with unexpected obstacles and looking for a way for the chronic matters, the resilient school leaders should be open to the new ideas.

Resilient leaders strong enough to deal with the complex problems, focus on the details, and try to see the latent and inexplicit relations among the events. When they face serious matters they think that at least one remedy exists. In turn, as good thinkers they know well that the social matters are multidimensional and connected each other. This complexity perspective can be helpful for the leaders and their teams for beating the odds.

Constantly reading $\&$ search is also one of the important characteristics of the resilient leader. This is needed to receive more information, eliminating the disinformation for coping with the obstacles. Also it makes the leaders more diligent, calm, and perspective in working among the obstacles. Mostly the reason that the problems occur is lack of information. For instance, a school leader who does not know the strategies of conflict management can cause serious problems when he or she experiences a conflict with a teacher. Even behaving without sufficient information can provide produce organizational pains.

\section{Emotionally Resilience}

Working and leading among the various obstacles the leaders can meet with emotional collapse, feeling wretched, despair, sorrow, passion, or loneliness. Before anything else the resilient leaders should be calm and think that "it is not the end of the world". According to the Brain-based Learning Theory, the brain works well without negative feels. For that, he or she is needed to focus on "how we gonna fix it?" instead of the "why does it emerge?"

Resilient leaders love their job, does not feel exhaustion, and give importance to the reason to be in the organization. They are decisive, have strong belief, and focus on achieving. Moreover, they are not pitiless or soulless but make empathy to understand the people and their needs in the organization. Empathy should not be a factor to diminish the resilience. In particular, the resilient leaders keep common sense, and invite the all to obey this in the organization.

Trying to solve the organizational matters or making something for improvement entails to behave courageously. But such courage should not be carelessly or gallingly, but be wisely. Showing "wise courage" makes the leaders be confident for taking a step, be good model for all, be prepared against 
coping with the obstacles they face in or out of the organization. In the today's world we know well that doing nothing, hiding or scaring in the world are not available instruments that the resilient leaders need.

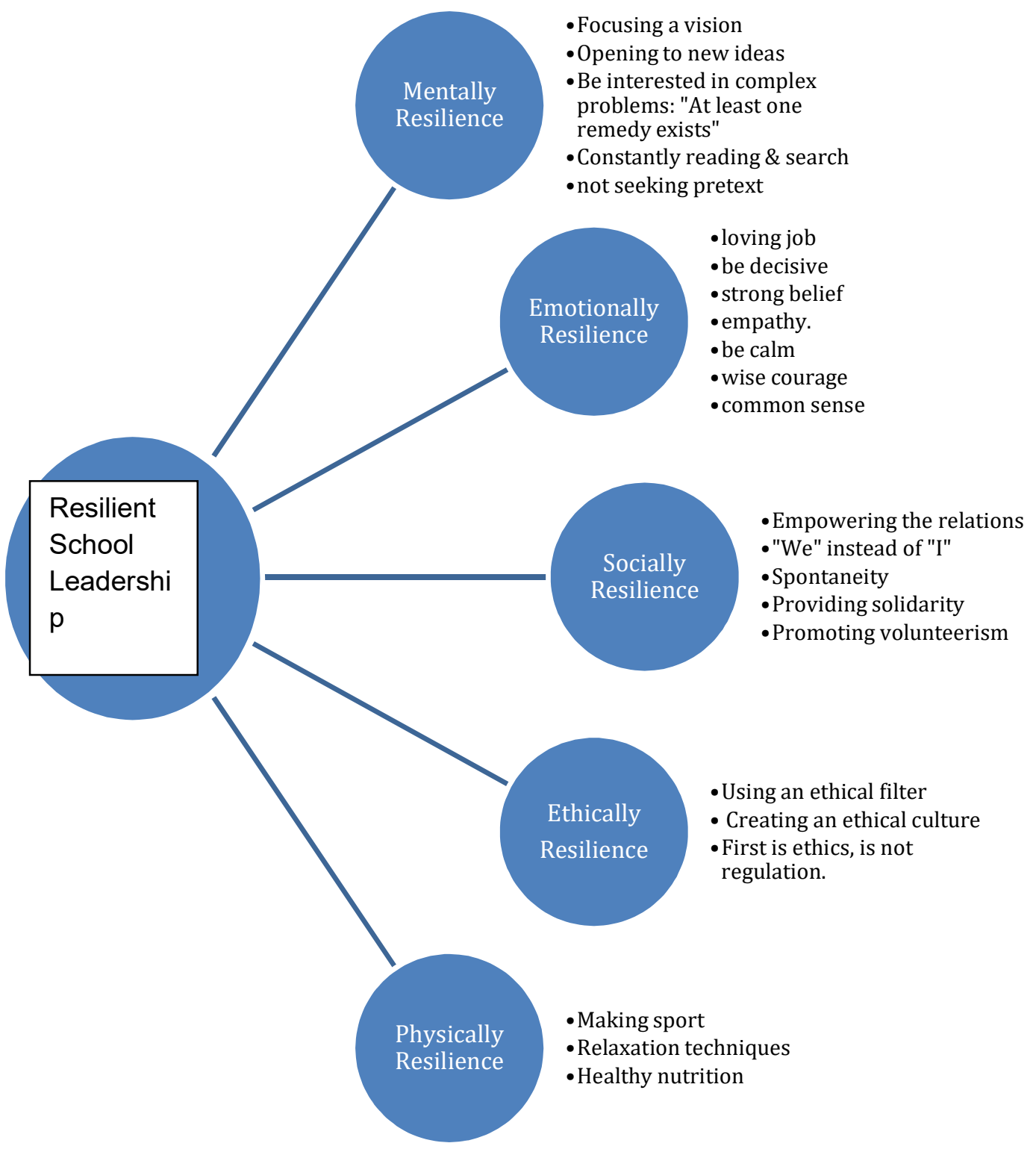




\section{Socially Resilience}

The obstacles in an organization can cause the leaders to be lonely, isolated from the stakeholders, to act alone in decision making process, even be authoritarian or apathy. Despite everything, the resilient leaders pay attention to the relations, and see their organizations in which they live together the stakeholders. In particular, they are not offended at someone or groups in the organization, but try to sustain the relations. And, such leaders seriously care about providing solidarity in their organization. It can also be explained as being "we" instead of "I". At the same time, when implementing these endeavors the resilient leaders act spontaneously/naturally.

Apart from the formal duties such as holding meeting, implementing the regulations from upper units of organization, budgeting, student affairs and something else; the other works such as especially developing the school and relations, and providing aid and support can be ensured through promoting volunteerism.

\section{Ethically Resilience}

"First is ethics, is not regulation" since the formal regulations do not indicate all, and the details for how to act in unexpected situations or in coping with the obstacles during non-ideal situations occur. To abide by ethics does empower the leaders. Because, ethics is more humanistic than the others. In this respect, resilient school leaders use an ethical filter to be applied for their behaviors in and out of the school. Applying this approach the leaders create an ethical culture that invites the others to behave ethically in the organization. Also the resilient leaders are aware of that behaving ethically is more valuable than using power in the organization. Just as Lord Acton said that "power corrupts and absolute power corrupts absolutely"

\section{Physically Resilience}

Working constantly in difficult conditions, and trying to be resilient for the obstacles can make the other type of leaders tired, exhausted, nervous, or fragile. But for this type of leaders, they should be resilient physically as well through relaxation techniques, making sport, sleep well, healthy nutrition, etc.

We cannot expect a serious effort to struggle with difficulties from a school leader who is physically tired, insensitive, and exhausted. We know the athletes: They are constantly training, pay attention to what they eat or drink, also try to stay fit. Why not expect similar from the school leaders? 


\section{Conclusion Remarks}

The present study conceptualizes a resilient leadership model with reference to the school system in the face of chaos and complexity. They may not be superman or supergirl but at least they are mentally, emotionally, socially, ethically, and physically strong humans who beat the odds. In turn, resilient leadership can be defined as displaying high level of endeavor to overcome the both internal and external obstacles that the organization faces, and generating different solutions despite the fact that many non-ideal situations affect the organization.

The studies conducted in the school leadership literature base on the Western-centered ideology and were produced mainly by the authors from USA, the UK, and Australia (Ahnee-Benham \& Napier, 2002; (Bush, 2014); Shockley (2008). The literature also focused on general and theoretical leadership issues (Ozmusul, 2015). Moreover, most leadership models or theories have been developed in the business management, after that they are adapted into the educational leadership. However, the context of education and school systems differ from the business sector. For that, it seems clearly that the conceptual frameworks based on the school context directly are needed.

At this point, the study has a potential to contribute to the school leadership literature from the education context. Nevertheless, the model suggested in this study is not a general one such as instructional leadership or transformational leadership that are written and discussed enormously in the educational leadership literature, but seems conceptual views and individual observations of the author from Turkish context.

And, we know well that each research paper bases on a research paradigm, and indicates it's weak and strong features. This paper seems "interpretivist" that argues that reality comes from people's subjective experiences on the social environment. As a result, I tried to explain some potential characteristics of the resilient school leadership through interpretivist perspective. And the study is open to discuss, critiques, and improvement. It is possible to give more samples and dimensions. I tried to contribute to the leadership process that is mysterious, complex, and incomplete by focusing on the resilience concept.

It can be also said that this conceptual model I suggest is not better than the others. But, it can be useful for the policies on selecting, appointment, and training needs of school leaders. Last but not least if the leadership is a teachable process the resilient leadership is teachable too.

In terms of reforming the selection process of the school administrators/leaders, the candidates can be asked "Are you resilient as a candidate school leader/administrator to beat the odds in the disadvantaged areas?" and/or "if you could work in a disadvantaged area or in the face of limited 
sources what would you do to improve the school? At this point what kind of projects do you dream?" The samples can be increased according to the school context.

Nevertheless, sustaining the resilient leadership without available educational policy and implementations take into account the school context and realities will be difficult, because there is a breakpoint of each resiliency. The school systems, policymakers in education should not wait everthing from the school leaders in the face of unsuitable conditions, and limited resources.

\section{Resources}

Ahnee-Benham, M. K., \& Napier, L. A. (2002). An alternative perspective of educational leadership for change: Reflections on native/indigenous ways of knowing. In Second international handbook of educational leadership and administration (pp. 133-165). Netherlands: Springer

Bayar, A. (2016). Challenges Facing Principals in the First Year at Their Schools. Universal Journal of Educational Research, 4(1), 192-199.

Bush, T. (2014). School leadership in Europe: growing the field. Educational Management Administration \& Leadership, 42(4s-S), 3-4.

Sagan, C. (1997). The demon-haunted world: Science as a candle in the dark. Random House Digital, Inc..

De Jong, D., Grundmeyer, T., \& Yankey, J. (2017). Identifying and addressing themes of job dissatisfaction for secondary principals. School Leadership \& Management, 1-18.

Hargreaves, A. G. Halász and B. Pont (2008), “The Finnish Approach to System Leadership", a case study report for the OECD Improving School Leadership activity, in Pont, B., D. Nusche and D.

Hopkins (eds.), Improving School Leadership, Volume 2: Case Studies on System Leadership, OECD, Paris.

$\mathrm{Ng}, \mathrm{P} . \mathrm{T}$. (2015). Aspiring principals' perception of the challenges of beginning principals and the support that they need. Asia Pacific Journal of Education, 35(3), 366-376. 
OECD. (2008). Improving school leadership, volume 1: policy and practice. Retrieved from https://www.oecd.org/edu/school/44374889.pdf

Ozmusul, M. (2015). The Unblocking Leadership for Effectiveness of Teachers as Knowledge Staff: A Theoretical Framework for School Management. Universal Journal of Educational Research, 3(10), 757-773., Doi: 10.13189/ujer.2015.031015.

Preston, J. P., Jakubiec, B. A., \& Kooymans, R. (2013). Common Challenges Faced by Rural Principals: A Review of the Literature. Rural Educator, 35(1), n1.

Shaked, H., \& Schechter, C. (2017). School principals as mediating agents in education reforms. School Leadership \& Management, 37(1-2), 19-37.

Shockley, K. G. (2008). Africentric education leadership: theory and practice. International Journal of Education Policy \& Leadership, 3(3), 1-12.

Shoho, A. R., \& Barnett, B. G. (2010). The Realities of New Principals: Challenges, Joys, and Sorrows. Journal of School leadership, 20(5), 561-596.

Whitaker, K. S. (2003). Principal role changes and influence on principal recruitment and selection: An international perspective. Journal of Educational Administration, 41(1), 37-54.

Wise, D. (2015). Emerging Challenges Facing School Principals. Education Leadership Review, 16(2), 103-115. 